\title{
Oxidative Degradation of Starch by Free Radical Systems Part II. Degradation of Starch and Other Polysaccharides in Solution
}

\author{
By Kazufumi YAGI \\ Research Institute, Kobe College, Okadayama, Nishinomiya \\ (Received for publication, December 4, 1968)
}

\begin{abstract}
Starch, amylopectin, carboxymethyl-starch and-cellulose, pectin, and alginic acid were found to be susceptible to degradation or depolymerization at ordinary temperature in the presence of free radical producing systems containing hydrogen peroxide and the synergist such as ascorbic acid, erythorbic acid, or ferrocyanate. Degree of depolymerization of amylopectin in terms of viscosity reduction was found to be proportional to the levels of free radical producing agents used.
\end{abstract}

It has been reported in the previous paper'), that the aqueous starch suspension gave modified starch of remarkably reduced viscosity when treated with hydrogen peroxide $\left(\mathrm{H}_{2} \mathrm{O}_{2}\right)$ in the presence of free radical producing synergist such as ascorbic acid (AsA), erythorbic acid (D-araboascorbic acid), hydrazine, or hydroxylamine. It was also very interesting to learn that viscosity reduction could be regulated arbitrarily by use of appropriate levels of $\mathrm{H}_{2} \mathrm{O}_{2}$ and the synergist.

It should be noted here that the above mentioned findings were the results of studies on the degradation of amylopectin in solution by $\mathrm{AsA}-\mathrm{H}_{2} \mathrm{O}_{2}$ system which is one of the subjects of the present report. In this connection, the present paper deals with further studies on the degradation of various polysaccharides in solution by free radical systems.

\section{Experimental and Results}

1) Degradation of amylopectin by $\mathrm{As} \mathrm{A}-\mathrm{H}_{2} \mathrm{O}_{2}$ system

Three hundred and fifty $\mathrm{mg}$ of corn amylopectin (moisture, 8.55\%), prepared according to Schoch's method ${ }^{2}$ ) and dissolved in $25 \mathrm{ml}$ of McIlvain's citrate-phosphate buffer ( $\mathrm{pH} 7.0)$, were mixed with $21.5 \mathrm{mg}\left(6.25 \times 10^{-4}\right.$ mole) of $\mathrm{H}_{2} \mathrm{O}_{2}$ and various amounts of AsA, and the total volume of the reaction mixture was made to $35 \mathrm{ml}$ with distilled water. Viscosity changes were measured periodically by treating $15 \mathrm{ml}$ of the reaction mixture with Ostwald viscometer at $40^{\circ} \mathrm{C}$, and changes of specific viscosity were plotted against time. Combined effect of AsA and $\mathrm{H}_{2} \mathrm{O}_{2}$ was obvious when compared to the effects of the two reagents used independently (curves $\mathrm{E}$ and $\mathrm{F}$ in Fig. 1). Molar ratio of amylopectin, AsA, and $\mathrm{H}_{2} \mathrm{O}_{2}$ was approximately 3:1:1 when $110 \mathrm{mg}$ of AsA was used.

As shown in Fig. 1, degradation of amylopectin by $\mathrm{H}_{2} \mathrm{O}_{2}$ was accelerated in- 


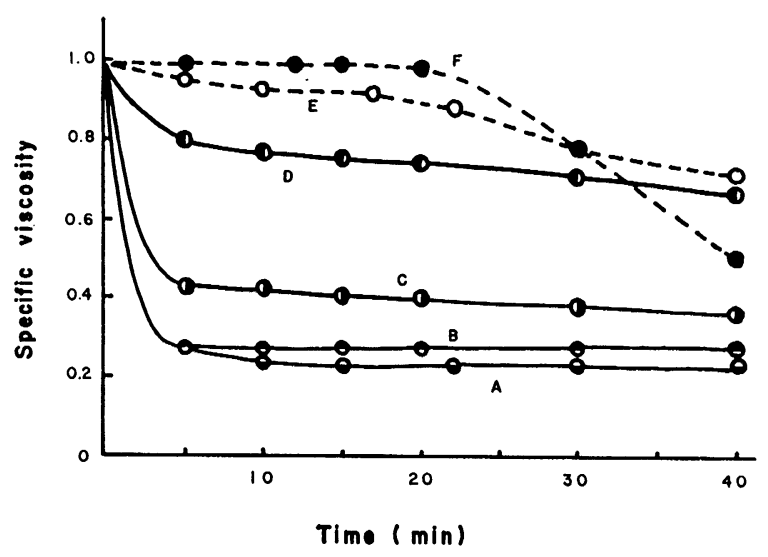

Fig. 1. Degradation of amylopectin by AsA- $\mathrm{H}_{2} \mathrm{O}_{2}$. Amount of AsA, mg: A, 110; B, 55; C, 27; D, 11; E, 0; F, 110 without $\mathrm{H}_{2} \mathrm{O}_{2}$.

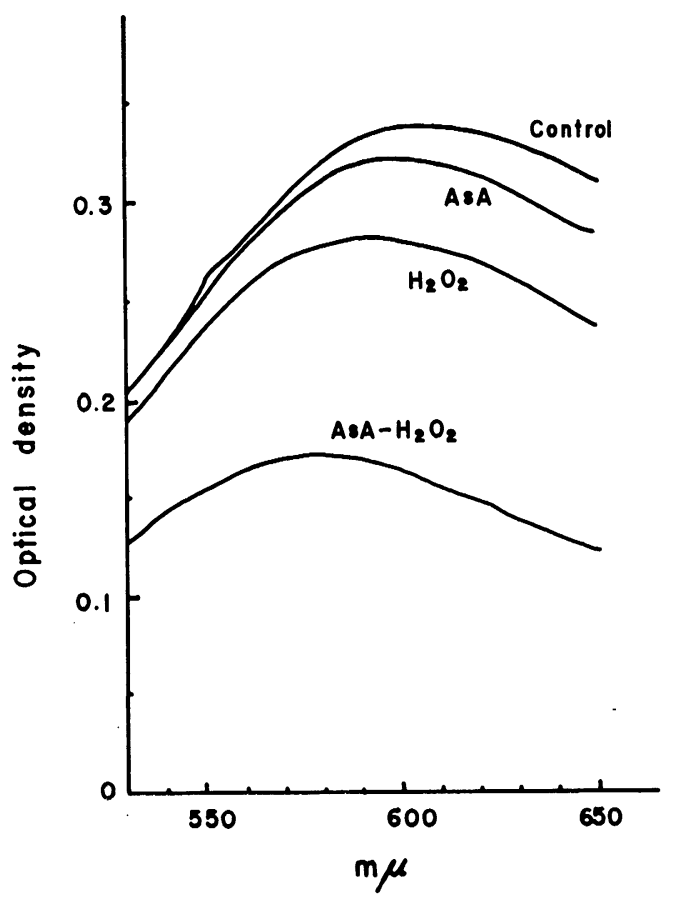

Fig. 2. Change in iodine coloration of amylopectin by $\mathrm{AsA}-\mathrm{H}_{2} \mathrm{O}_{2}$ treatment. Reaction mixture, $70 \mathrm{ml}$, containing $700 \mathrm{mg}$ of corn amylopectin in $50 \mathrm{ml}$ of McIlvain's citrate-phosphate buffer ( $\mathrm{pH} \mathrm{7.0),} 42.5 \mathrm{mg}$ of $\mathrm{H}_{2} \mathrm{O}_{2}$, and $110 \mathrm{mg}$ of AsA, was maintained at $40^{\circ} \mathrm{C}$ for $60 \mathrm{~min}$, followed by dialysis against tap water for several days to remove unchanged AsA and $\mathrm{H}_{2} \mathrm{O}_{2}$. After dilution of dialyzed reaction mixture to $250 \mathrm{ml}, 25 \mathrm{ml}$ aliquot was taken and diluted to $250 \mathrm{ml}$ after addition of $20 \mathrm{ml}$ of $0.005 \% \mathrm{I}_{2}-\mathrm{KI}$ solution. Optical densities were measured at various wave lengths ranging from 530 to $650 \mathrm{~m} \mu$. 
creasingly to a certain extent with increasing amount of added AsA. Viscosity lowering was only gradual after initial intense degradation.

To get some information about changes in amylopectin molecule during AsA$\mathrm{H}_{2} \mathrm{O}_{2}$ treatment, iodine coloration and reducing activity were observed after dialysis of the reaction mixture to remove residual reagents which disturb these two observations. Combined effect of the two reagents was demonstrated by the changes in iodine coloration which showed simultaneous occurrence of decrease in optical densities and the shift of $\lambda \max$ to shorter wave length (Fig. 2). The same effect can be seen in Table I which shows remarkable development of reducing moiety by AsA- $\mathrm{H}_{2} \mathrm{O}_{2}$ treatment.

Table I. Development of Reducing Activity of Amylopectin by AsA- $\mathrm{H}_{2} \mathrm{O}_{2}$ Treatment

Reaction mixture, $60 \mathrm{ml}$, containing $700 \mathrm{mg}$ of corn amylopectin in $50 \mathrm{ml}$ of McIlvain's citrate-phosphate buffer ( $\mathrm{pH} \mathrm{7.0)}, 42.5 \mathrm{mg}$ of $\mathrm{H}_{2} \mathrm{O}_{2}$, and $110 \mathrm{mg}$ of $\mathrm{AsA}$, was maintained at $40^{\circ} \mathrm{C}$ for $40 \mathrm{~min}$, followed by dialysis against tap water for several days to remove unchanged AsA and $\mathrm{H}_{2} \mathrm{O}_{2}$. After dilution of dialyzed reaction mixture to $250 \mathrm{ml}, 1 \mathrm{ml}$ aliqot was taken for reducing activity measurement by usual 3,5-dinitrosalicylic acid method. Reaction mixtures containing only one of the two reagents were also treated and analyzed as described above.

\begin{tabular}{c|c|c|c|c}
\hline \hline & Control & AsA & $\mathrm{H}_{2} \mathrm{O}_{2}$ & AsA- $\mathrm{H}_{2} \mathrm{O}_{2}$ \\
\hline Optical density at $530 \mathrm{~m} \mu$ & 0.017 & 0.021 & 0.000 & 0.220 \\
\hline
\end{tabular}

\section{2) Observation of degradation by Amylograph}

Potato starch (20 g, dry basis), suspended in $450 \mathrm{ml}$ of distilled water, was heated gradually $\left(1.5^{\circ} \mathrm{C} / \mathrm{min}\right)$ in Brabender Amylograph from $30^{\circ} \mathrm{C}$ to $75^{\circ} \mathrm{C}$ and cooled with the same rate to $50^{\circ} \mathrm{C}$ and kept at this temperature for $10 \mathrm{~min}$. Then, $5 \mathrm{ml}$ of AsA solution followed by $5 \mathrm{ml}$ of $\mathrm{H}_{2} \mathrm{O}_{2}(10 \%)$ was added to the paste, and the viscosity changes were recorded automatically at $50^{\circ} \mathrm{C}$. Fig. 3 shows that the

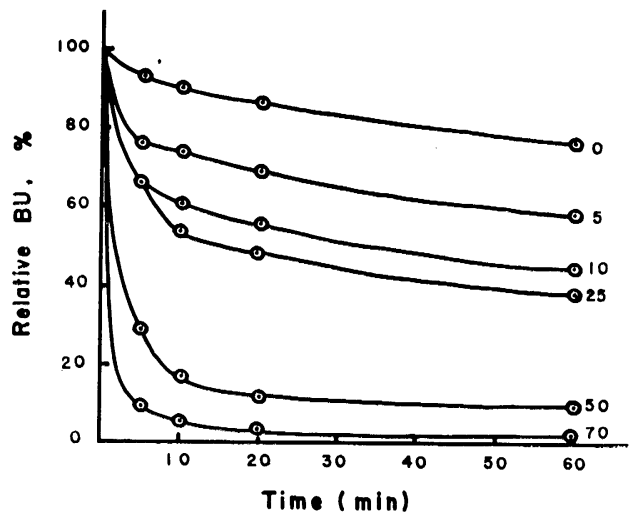

Fig. 3. Degradation of potato starch paste by AsA- $\mathrm{H}_{2} \mathrm{O}_{2}$ system observed by amylograph at $50^{\circ} \mathrm{C}$. Figures on the curves denote the amount $(\mathrm{mg})$ of AsA added. 
viscosity changes resulted by various levels of added AsA were plotted against time. For convenience, viscosity on the ordinate is expressed as \% Brabender Unit (BU) based on the initial $\mathrm{BU}$ of the paste at $50^{\circ} \mathrm{C}$.

Here again, exalting effect of AsA was also proved in the degradation of highly viscous starch paste containing $\mathrm{H}_{2} \mathrm{O}_{2}$.

3) Degradation of starch by various free radical systems other than $\mathrm{AsA}-\mathrm{H}_{2} \mathrm{O}_{2}$

A system containing potassium ferrocyanate and $\mathrm{H}_{2} \mathrm{O}_{2}$, a modified Fenton reagent, has been known as a powerful reagent producing free hydroxyl radical, and this was compared with the effect of AsA- $\mathrm{H}_{2} \mathrm{O}_{2}$.

Potato starch ( $2.5 \mathrm{~g}$, dry basis) was gelatinized with about $20 \mathrm{ml}$ of hot water. After cooling, $25 \mathrm{ml}$ of $1 \mathrm{~N} \mathrm{NaOH}$ and about $100 \mathrm{ml}$ of water was added followed by neutralization with $1 \mathrm{~N} \mathrm{HCl}$. Water was then added to make $250 \mathrm{ml}$ of transparent starch solution.

Reaction mixture was prepared by mixing $25 \mathrm{ml}$ of starch solution, $5 \mathrm{ml}$ of $3 \%$ $\mathrm{H}_{2} \mathrm{O}_{2}$, and $5 \mathrm{ml}$ of $0.1 \mathrm{~m}$ synergist solution. Viscosity changes were measured by Ostwald viscometer at $30^{\circ} \mathrm{C}$. As shown in Fig. 4, the effect of ferrocyanate was found to close up to that of AsA in accordance with increased concentration of ferrocyanate.

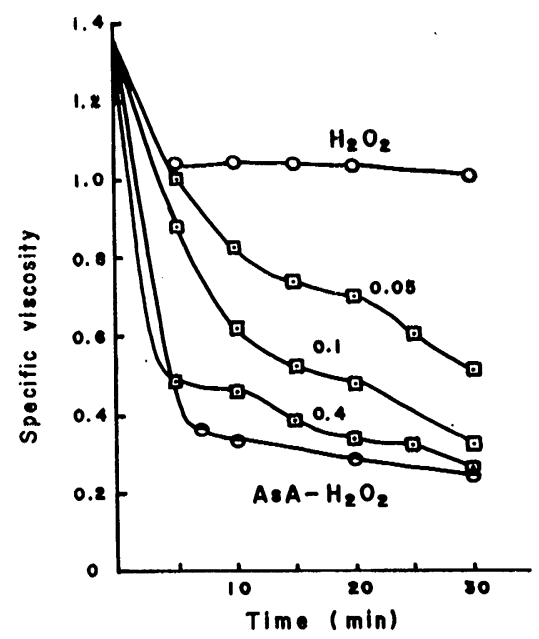

Fig. 4. Degradation of starch by $\mathrm{H}_{2} \mathrm{O}_{2}-$ ferrocyanate system. Figures on the curves denote the molar concentration of ferro cyanate solutions used.

Ferrous ion, D-araboascorbic acid, hydroxylamine, and hydrazine were reported previously to have synergistic action with $\mathrm{H}_{2} \mathrm{O}_{2}$ in the heterogeneous degradation of starch granules. ${ }^{1)}$ These systems were again proved to behave similarly to, but less effectively than AsA- $\mathrm{H}_{2} \mathrm{O}_{2}$ system (data are not shown). 


\section{4) Degradation of various polysaccharides other than starch}

Several kinds of polysaccharides were chosen to compare the viscosity decrease during oxidative degradation by use of erythorbic acid* (EA; D-araboascorbic acid) $\mathrm{H}_{2} \mathrm{O}_{2}$ system controlled under similar reaction condition. Reaction mixture consisted of each $25 \mathrm{ml}$ of the following polysaccharide solutions having appropriate viscosity, $10 \mathrm{ml}$ of $1 \% \mathrm{EA}$, and $5 \mathrm{ml}$ of $0.3 \% \mathrm{H}_{2} \mathrm{O}_{2}$. The reaction mixture $(15 \mathrm{ml})$

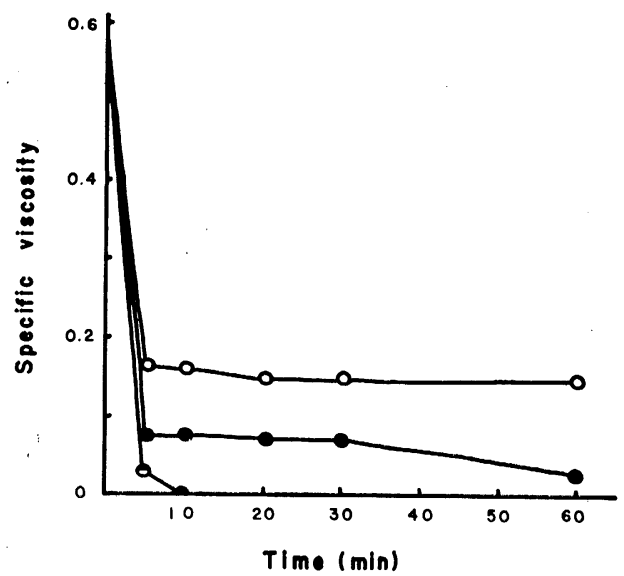

Fig. 5. Degradation of CMS by EA$\mathrm{H}_{2} \mathrm{O}_{2}$ system. - $\mathrm{O}-\mathrm{H}_{2} \mathrm{O}_{2}$ only, EA only, $-\mathrm{H}_{2} \mathrm{O}_{2}+$ EA.

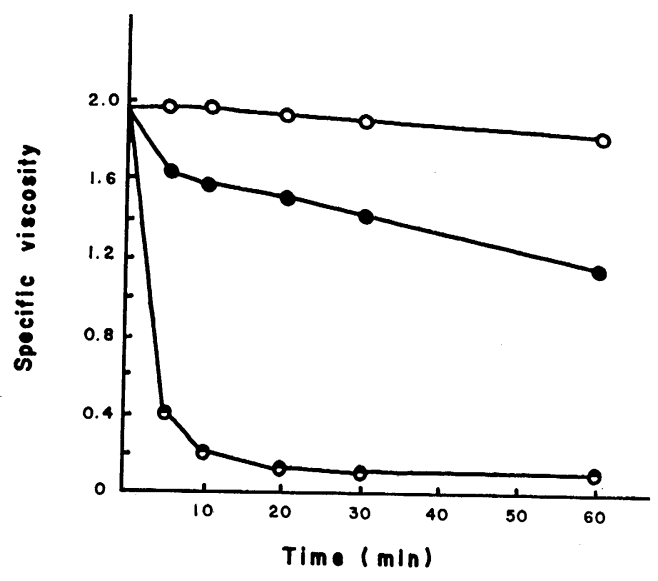

Fig. 7. Degradation of pectin by EA$\mathrm{H}_{2} \mathrm{O}_{2}$ system.

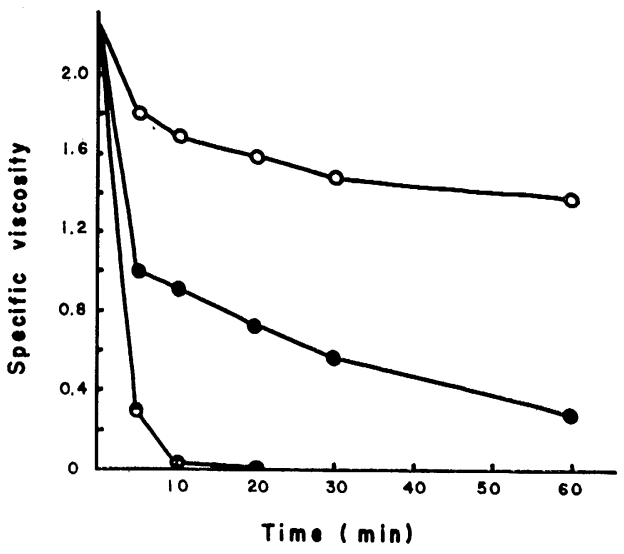

Fig. 6. Degradation of CMC by EA$\mathrm{H}_{2} \mathrm{O}_{2}$ system.

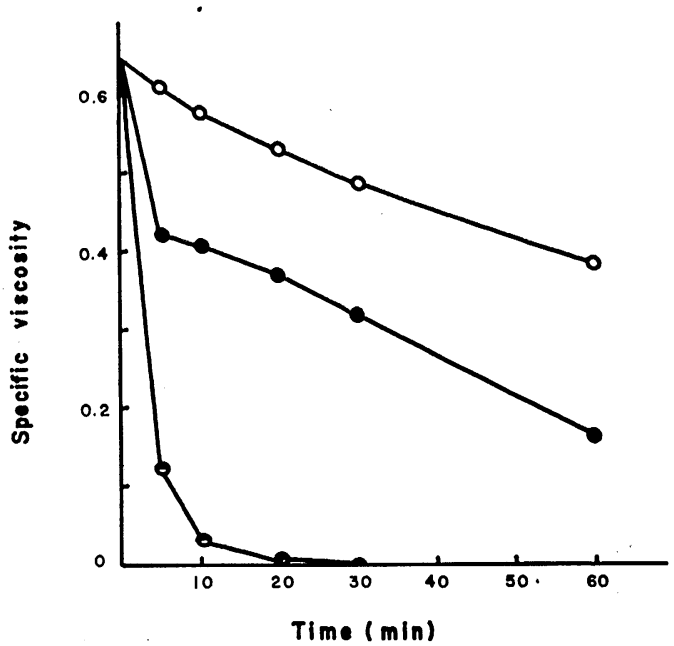

Fig. 8. Degradation of alginic acid by EA- $\mathrm{H}_{2} \mathrm{O}_{2}$ system.

* Kindly supplied by Fujisawa Pharmaceutical Co. Ltd., Osaka. 
was taken in Ostwald viscometer and the measurement was done at $40^{\circ} \mathrm{C}$. The results are shown in Figs. 5-8.

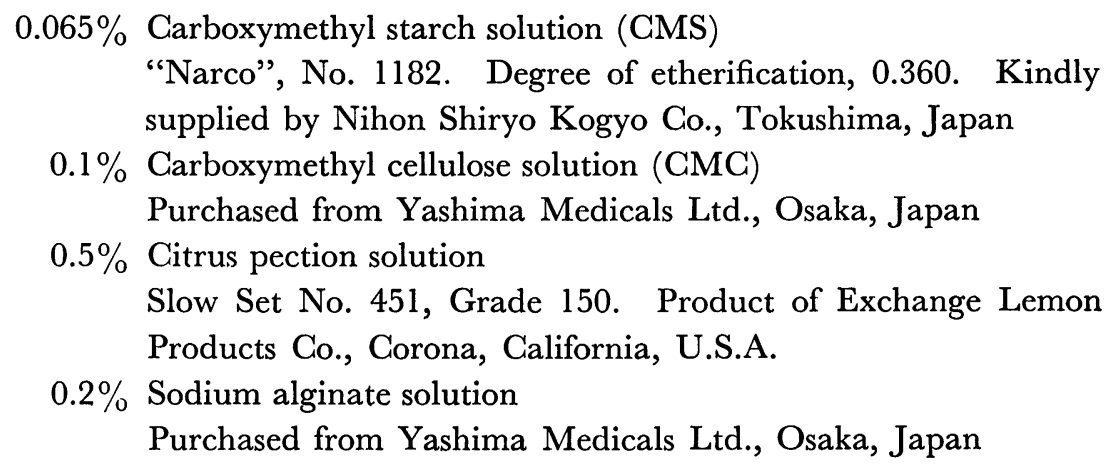

\section{Discussion}

By several scattered informations, polysaccharides, glycoproteins, and nucleic acids have been shown to be susceptible to "oxidative-reductive depolymerization". ${ }^{3}$ ) This action is characterized by the participation of free radicals produced by various autoxidants such as reductones (ascorbic acid and the like) or thiols. These autoxidants react with molecular oxygen to produce hydrogen peroxide via intermediate free radicals. The mechanism is proposed, for instance, as follows:

$$
\begin{aligned}
\mathrm{AH}_{2} & \rightarrow \mathrm{AH}^{-}+\mathrm{H}^{+} \\
\mathrm{AH}^{-}+\mathrm{Cu}^{++} & \rightarrow \mathrm{AH} \cdot+\mathrm{Cu}^{+} \\
\mathrm{AH} \cdot+\mathrm{Cu}^{++} & \rightarrow \mathrm{A}+\mathrm{Cu}^{+}+\mathrm{H}^{+} \\
2 \mathrm{Cu}^{+}+2 \mathrm{H}^{+}+\mathrm{O}_{2} & \rightarrow 2 \mathrm{Cu}^{++}+\mathrm{H}_{2} \mathrm{O}_{2} \\
\mathrm{AH}_{2}+\mathrm{O}_{2} & \rightarrow \mathrm{A}+\mathrm{H}_{2} \mathrm{O}_{2} \\
\mathrm{RSH}+\mathrm{O}_{2} & \rightarrow \mathrm{RS} \cdot+\mathrm{HO}_{2} \cdot \\
\mathrm{RSH}+\mathrm{HO}_{2} \cdot & \rightarrow \mathrm{RS} \cdot+\mathrm{H}_{2} \mathrm{O}_{2} \\
2 \mathrm{RS} & \rightarrow \mathrm{RSSR} \\
2 \mathrm{RSH}+\mathrm{H}_{2} \mathrm{O}_{2} & \rightarrow \mathrm{RSSR}+2 \mathrm{H}_{2} \mathrm{O} \\
4 \mathrm{RSH}+\mathrm{O}_{2} & \rightarrow \mathrm{RSSR}+2 \mathrm{H}_{2} \mathrm{O}
\end{aligned}
$$

In this sequence, $\mathrm{AH}_{2}, \mathrm{AH} \cdot$, and $\mathrm{A}$ denote reduced ascorbic acid, ascorbate free radical, and dehydroascorbic acid, respectively.

$\mathrm{AH}_{2}$ can react with $\mathrm{H}_{2} \mathrm{O}_{2}$ regardless whether it is produced from autoxidizing $\mathrm{AH}_{2}$ or added to a system containing $\mathrm{AH}_{2}$. Although the mechanism of interaction of $\mathrm{AH}_{2}$ with $\mathrm{H}_{2} \mathrm{O}_{2}$ has been shown to be very complicated, it is certain that the reaction is catalyzed by trace amount of transition metal ion ( $\mathrm{Fe}, \mathrm{Gu}$, etc.), and involves intermediate formation of free radicals such as free hydroxyl radical $(\cdot \mathrm{OH})$ 
and ascorbate free radical (AH•). These free radicals are considered responsible for the degradation of high polymers.

Viscosity reduction of amylopectin by $\mathrm{H}_{2} \mathrm{O}_{2}$ in the presence of varying amount of $\mathrm{AH}_{2}$ was found to be very intense during initial few minutes and only gradual thereafter, and the degradation was accelerated increasingly with increasing amount of added $\mathrm{AH}_{2}$ (Fig. 1). Similar results were also shown in Fig. 2 where thick starch paste became thinner to reach certain level of reduced viscosity. These interesting findings have been successfully applied to the convenient preparation of oxidized starch having viscosity reduced to arbitrary level, in which aqueous starch suspension was treated with certain levels of $\mathrm{AH}_{2}$ and $\mathrm{H}_{2} \mathrm{O}_{2}$ at ordinary temperature ${ }^{1)}$.

Although change in iodine coloration and development of reducing activity caused by $\mathrm{AH}_{2}-\mathrm{H}_{2} \mathrm{O}_{2}$ treatment are quite evident from the results shown in Table I and Fig. 2, it is not certain whether these were the result of hydrolysis of glucosidic linkage or of oxidative cleavage in anhydroglucose units or of both. Previous paper ${ }^{1}$ seems to support that this degradation is the results of both hydrolysis and cleavage as proved by enzymic digestibility.

Ferrocyanate, in place of AsA, was found to be capable to reduce viscosity of starch in solution when used together with $\mathrm{H}_{2} \mathrm{O}_{2}$ (Fig. 4). This system, however, is far less effective than AsA- $\mathrm{H}_{2} \mathrm{O}_{2}$ system in heterogeneous reaction using starch suspension (unpublished data).

As a series of preliminary experiment, various polysaccharides were chosen to compare viscosity reduction by $\mathrm{EA}-\mathrm{H}_{2} \mathrm{O}_{2}$ treatment. Although synergistic action of EA and $\mathrm{H}_{2} \mathrm{O}_{2}$ was obvious in all cases tested (Figs. 5-8), it was especially small in the case of CMS. It was suggested that polymers containing carboxyl or ester groups seem particularly sensitive to free radical degradations, and polyuronic acids such as hyaluronic acid and pectins have been the most studied. Synthetic high polymers having no glycosidic linkage such as polymethacrylic acid ${ }^{4}$ and polyvinyl alcohol (unpublished data) were found to be degraded readily by autoxidizing systems. This means that oxidative cleavage of $\mathrm{G}-\mathrm{C}$ bond should take place.

In this connection, relation between chemical sturctures of high polymers and their susceptibility to free radical degradation must be the project of future research.

\section{References}

1) Yagi, K. and Suzuki, H., Agr. Biol. Chem., 29, 447 (1965).

2) Schoch, T. J., J. Am. Chem. Soc., 64, 2957 (1942).

3) Pigman, W., Rizvi, S. and Holly, H. L., Arthritis Rheumat., 4, 240 (1961).

4) Alexander, P. and Fox, M., J. Polymer Sci., 23, 493 (1958). 